\title{
The French Colonial Imagination. Writing the Indian Uprisings, 1857-1858, from Second Empire to Third Republic NICOLA FRITH
}

Lanham, Boulder, New York, Toronto, Plymouth, UK: Lexington Books, 2014

228 pp, £49.95, ISBN 978-0-7391-8000-6 (cloth), 978-0-7391-8001-3 (electronic)

This interesting book takes as its subject the French response to the Indian Uprisings of 18571858, variously referred to as the 'Mutiny' or 'The First Indian War of Independence'. It focuses on representations of these events in the contemporary French press, as well as in fiction and non-fiction works, published in subsequent years. These representations not only throw light on Franco-British colonial rivalry but, it is argued, illustrate the way the French colonial imagination was constituted in the period spanning the Second Empire and the Third Republic and how the lessons supposedly learned from the British experience in India were applied to France's own colonial empire, particularly in Algeria. There is much focus on the important role nostalgia for France's 'lost empire' was to play in the expansion and ideology of French colonialism in the late nineteenth century. In this, the reference to British colonialism is considered vital, initially as an example to emulate, but then as a model against which France should distinguish itself with its supposedly superior, morally grounded, 'Republican' civilising mission.

This approach fits well with the triangulated French India studies paradigm developed at Liverpool University by Kate Marsh, Ian Magedera and others. This involves subverting the East/West binary and prioritising the specificity of French colonialism in India, determined as it is by its subordinate position in relation to the dominant British colonising power. This relation has allowed free rein to the imagination, in a nostalgic idealism that fantasises about what an Inde française might have been but never was (p.6).

This is a scholarly, well-referenced work, though not devoid of errors, as the claim that Bahadur Shah II was executed (p.16), or escaped (p.43) when, in fact, he was exiled to Burma. However, it is not intended as a contribution to the history of these events as such, nor to the historical debates they continue to provoke. Rather it analyses the significance of French representations of the uprisings for an understanding of subsequent developments in French colonial expansion and, especially, in the discourses through which they are articulated. Many of these accounts seize on the events and the British response to them as a sign of weakness on the part of the imperial rival. The book thus throws light on the different ways in which the French and the British colonial discourses encounter and respond to anticolonial resistance. While the French may represent figures like Nana Sahib and the Rani of Jhansi in a more positive revolutionary light, this is usually set against the backdrop of a critique of the British failure to carry out its colonial civilising mission successfully. The terminology used stresses the 'revolutionary' nature of the revolts and their main players, unlike the British, who sought to downplay any suggestion that they represented a popular, 'national' revolt, rather than a military 'mutiny'. One might argue that the reality lies elsewhere, given that the 1857-8 events did not represent a modernist, European-style revolution, but focused mainly on turning back the clock and re-establishing feudal-type rulers in their domains.

This is not, however, the aim of this book, which, while it succeeds in illuminating the 'discursive rivalry' between both imperial powers, does not fail to distinguish between the often delusional ideological, imaginary discourse and the realities on the ground, where the similarities between them outweigh the differences. 